\title{
Historians, religion and the historical record
}

\section{The origins of Enlightenment anticlericalism}

The politico-religious convulsions across Europe from the Reformation until the eighteenth century were numerous and bloody. The resulting religious divisions were enshrined in confessional states, but, as with the cases of Protestant England and Catholic France, religious minorities remained persecuted and disabled. It would have been truly miraculous if many Christians had not wearied of the constant conflict between and within opposing Churches and begun to question whether war and persecution should really be a feature of religion. Although Christianity certainly underwent change in this period, no antichristian religion or atheist groundswell arose to challenge it. This is, of course, not to say that atheism did not exist, but if it did, it remained a private matter and texts written by atheists quickly gained infamy by the fact of their rarity, and the same can be said of deism. The problem is that the Enlightenment is famous for its challenge to the Church, and the absence of antichristian movements in the immediate period preceding the Enlightenment has been frustrating for many historians. Being convinced that the Enlightenment - as traditionally understood - had to have had radical roots, there was always the danger that wishful thinking might mistake a few swallows for a summer. As Patrick Riley has put it in relation to the search for the origins of Rousseau's theory of the General Will, '[w] hen one is looking for something - influence, for example - one fails to find it only if one is lacking in ingenuity ... [and] that same ingenuity is ingenious enough to construct the object of its search, and to take that construction for a discovery'. ${ }^{1}$

In the absence of proof for the existence of antichristian 


\section{The Enlightenment and religion}

movements, however, it has still been possible to induce a number of sceptical or religiously radical texts to 'talk' to each other, producing an often fictitious or suppositious relationship with each other, and so constructing the semblance of a radical tradition or movement. This procedure was adopted, for instance, in Wade's Intellectual Origins of the French Enlightenment (1971). Having discussed various 'schools' of thought, but viewing Italy as the originator of the 'movement', Wade sums up by claiming that ' $[t]$ hroughout the closing years of the sixteenth century, and during the whole of the seventeenth down to the opening years of the eighteenth, there was always one or other of these groups to carry on the free-thinking tradition'. After informing us that this movement also continued into the eighteenth century, so influencing the major thinkers of the French Enlightenment, Wade then defines its status: 'Freethinking is thus one of the most consistent, coherent, and continuous intellectual movements in Europe we have'. ${ }^{2}$

Yet the story is not quite the same from Betts. In his Early Deism in France (1984), he illustrates how the contention that deist thought had a continuous history from the late sixteenth century cannot be proven. ${ }^{3}$ So, apparently, deism did not form part of the great tradition affirmed by Wade. He also reveals how relatively few French deist writings there were in the first two decades of the century, and how 'free-thought was either on the retreat or only in mild disagreement with orthodoxy' in the period $1725-41 .{ }^{4}$ Usefully, he also reminds the reader that ' $[t]$ here may be considerable doubt whether particular writers are Christians tending to deism or deists sympathetic to Christianity', and that 'in about 1715 deism comprised a combination of Christianity and rationalism'. Clearly, then, the historical record and the way it is approached can yield quantitatively and qualitatively different results. Betts, however, still adheres to the idea of a broad deistic or radically religious movement of sorts, for he informs us that '[it] is a matter of history that, roughly at the beginning of the eighteenth century, large numbers of individuals were in the process of detaching themselves from Christian belief and replacing it by a religious attitude in which the belief in God was independent, at least outwardly, of Church or Bible'. ${ }^{5}$ Unfortunately, he does not reveal the source for this epochmaking 'matter of history' that, in his account, is formative in the development of the Enlightenment. Perhaps needless to say, however, there is no substantial proof for such an assertion. 


\section{Historians, religion and the historical record}

So far we have been considering what might be termed the dominant trend in Enlightenment studies: the positing of a tradition of radical or extra-Christian Enlightenment roots. We must now, briefly, comment on the claim that Christian texts might, at least in part, be responsible for the development of the enlightened religious outlook. Kors, for instance, has claimed that '[i]t was, above all, within the deeply Christian learned culture of those years [late seventeenth and eighteenth centuries] that there occurred inquiries and debates that generated the components of atheistic thought' ${ }^{6}$ Elsewhere but on the same subject he explains that his thesis 'is precisely that in the late seventeenth and early eighteenth centuries, it was works written from unimpeachable motives, to guarantee the faith, that in fact "cleared the way" for the conceivability of atheistic philosophy'. ${ }^{7}$ Given their substantial claims, Kors et al. ${ }^{8}$ can bewail the fact that, hitherto, ' $[\mathrm{t}]$ he agency granted to the theological and religious movements of the preceding era had been at most that of an indirect facilitator ... opening a breach exploited by forms of rationalism, naturalism and religious skepticism'. ${ }^{9}$ Unfortunately, we are left to guess as to how to interpret the phrase 'cleared the way'. In sum, within elite debate, Kors and others have detected Christian ideas and positions which could, potentially, be turned against Christianity. Indeed, according to Kors, refutations of God (as hypothetical positions in orthodox writings) abounded by the late seventeenth century because of the theological polemic on the issue of the proper philosophical structure for Christian doctrine. ${ }^{10} \mathrm{We}$ may perhaps understand the term 'abounded' as somewhat of an exaggeration, but even if this were not the case, nowhere do Kors or others present evidence for influence. Hence, although the study of such learned works gives us an insight into the potential contradictions of thought at the time, they cannot be considered, in themselves, as proof of the exertion of influence upon Enlightenment origins.

One traditionally broad avenue of enquiry into the wider origins of the Enlightenment has been to chart the career of reason, the tool the philosophes viewed as central in the struggle for enlightenment. The explicit recourse to the tool of reason in Protestant religious discourse increased in the seventeenth century, so much so that by 1700 the criterion of reason was present in a significant proportion of Protestant writings and was especially visible in England. It has traditionally been argued that, in the late seventeenth 


\section{The Enlightenment and religion}

century, critics of the Church seized upon the tool of reason and turned it, to significant effect, against the Church. Reason thus became the watchword of the philosophes against the miraculous, the superstitious and backward tradition. As Cragg in his Reason and Authority in the Eighteenth Century (1964) put it, religious writers 'conceded the preeminence of reason; they were prepared to test revelation, as well as its evidences in miracle and prophecy, by the standards which reason suggested'. ${ }^{11}$ By comparison, in orthodox Catholic writings the use of reason was very much more limited, although more frequently present in dissident writings, including those of Jansenists. One of the key problems with tracing the career of reason as a guide to early modern religious change is that it was above all a polemical tool, and one with no defined content or manner of application. As such, its use was often indiscriminate and ad hoc; it could be utilized by anyone in almost any circumstance and cannot be, in itself, termed a sufficient guide to the identification of religious radicalism.

Where links between Christianity and enlightened thinking have been explored, they have most often been based upon precocious elements of elite theological discourse, rather than upon more common-or-garden or overtly sectarian polemics. Precocious movements and tendencies within Anglicanism have often been a focus of attention because of the perceived dynamism of religious change in early modern England, and also because of the recognition by most that developments there marked the earliest phase of the Enlightenment. Thus the Cambridge Platonists (1630s-80s, the most notable element of the Latitudinarian tendency) have been selected for detailed study on the basis of their desire for (relative) tolerance and their conception of reason as the arbiter both of natural and revealed religion. There is, however, little evidence so far adduced that the Cambridge Platonists or other Protestant writers such as Lord Herbert of Cherbury (1583-1648, traditionally known as the 'father' of deism) had any influence upon the development of English deism at all. Indeed, as Pailin has noted, '[a]part from Charles Blount the so-called deists hardly mention Herbert'. ${ }^{12}$ So, Herbert may be made to fit neatly into the 'tradition', where Herbert's writings are made to talk to others, but there is no evidence at all of influence. Pailin is certainly correct to point out the lack of references to Herbert, but most importantly - as we shall see below even if deists had cited Herbert, it would not necessarily constitute 


\section{Historians, religion and the historical record}

what historians very often cite as influence.

Charting the career of reason may, ostensibly, seem a search for the 'modern' amongst the traditional. Yet such a search only tells us substantially what we already know: the impasse of religious disagreement and concomitant polemical stalemate in seventeenthcentury Europe resulted in an elevation of the 'objective' tool of reason in religious polemic. In other words, for Enlightenment studies to focus on the career of reason is to focus more upon a symptom than a cause, upon a feature of religious polemic caused by and reflecting wide religious division. If this is the case, some comments on the traditional understanding of those religious divisions are therefore appropriate.

The end of the so-called mid-seventeenth-century European crisis - the widespread wars and revolts of the mid-century and especially the Thirty Years War (1618-48) - has traditionally been considered as a watershed marking the end of the 'last great European conflict in which religion was a vital element'. Most commentators have also been obliged to state the obvious and note that 'the substantial issues which concerned the protagonists were not directly religious', but of course economic and political. ${ }^{13}$ This was certainly apparent to many contemporaries and participants in those wars. Thus, in estimating the factors which contributed to the formation of seventeenth-century anticlericalism, it is an inescapable - but frustratingly difficult to measure - fact that the ideological form of those wars undoubtedly caused many to ask whether Jesus had ever intended Christian to fight Christian. The wars ended in 1648 with the Peace of Westphalia, by which time most rulers desired peace in which to recover from the protracted holocaust and reaffirm their rule. Thus historians have felt able to pronounce that the 'Reformation age of astonishing religious development and upheaval, but also of religious darkness, was coming to a close'. ${ }^{14}$

This traditional explanation surrounding the nature and significance of the sixteenth- and seventeenth-century wars and conflicts, however, is based partly upon assumption. It depends upon the assumption that the height of politico-religious crisis was reached around the mid seventeenth century, and that this was also considered to be the case by Enlightenment thinkers. There is certainly sufficient evidence to claim that many Christians before or around the mid-century were disillusioned by divisions within 


\section{The Enlightenment and religion}

Christianity and its political use. But what evidence is there to substantiate the claim that late-seventeenth- and eighteenth-century thinkers considered that post-Reformation 'religious darkness was coming to a close'? For those Dissenters struggling against the Anglican Church and state, for Huguenots and Jansenists in France and for other religious minorities across Europe, bitter and at times bloody religious conflict and persecution were still the order of the day. From this point of view, claims about the end of the mid-seventeenth-century crisis bringing a vision of peace to Christendom should not provide legitimation for ignoring or minimizing the importance of politico-religious conflicts yet to occur in the late seventeenth and eighteenth centuries.

So, it is time to return to the historical record and give more weight to the general politico-religious background in which lateseventeenth-century English thinkers lived. To give an example: it has been established that in the two decades after 1605 the pamphlet controversy with Rome alone saw over 500 anti-Catholic publications appear in England. ${ }^{15}$ Many of these were pamphlets and short tracts and were relatively popular in style. This is a substantial figure, yet needs to be revised and increased. It needs increasing because not all polemical tracts and pamphlets were anti-Catholic; some were anti-Puritan. It needs revision because some of the publications, notably those of Puritans, were deliberately dual-edged, ostensibly anti-Catholic, but also directed at what was considered the quasi-Catholicism of the Stuart kings. This great polemical effort to delegitimize religious opponents was not unique to England, but formed a central part of the religious competition between Protestants, Catholics and dissident thinkers across Europe.

With this scenario in mind, the term anticlericalism has a much broader application than is usually accorded it in the context of Enlightenment studies. We need to be quite clear on this point. For the century and a half prior to the Enlightenment, for the first time Europeans experienced permanent, institutionalized anticlericalism: Protestants and Catholics were anticlerical with regard to each other, and radical Protestants and Protestant established Churches likewise. As I have illustrated elsewhere, these permanent divisions saw the development of relatively sophisticated anticlerical theories, very often comparative and popular in style, ${ }^{16}$ developed and aimed at religious opponents. Those who have searched for the 


\section{Historians, religion and the historical record}

roots of modernity have looked insufficiently at intra-Christian polemical material because of their presupposition that evidence of modernity should take the form of secular or secularizing thought linked to a pronounced development of reason as a critical tool.

Perhaps the most vital battleground of the Christian polemical terrain was history. Protestants, Catholics and their subdivisions sought to demonstrate that the history of their religious opponents was, like that of pagan religions, little more than the history of priestcraft: religious fraud conducted in order to acquire wealth, political power and status, keeping the laity ignorant of true religion. So, part of the ideological heritage of the sixteenth and seventeenth centuries was a deeply ingrained comparative polemico-historical approach which remained in place until at least the end of the eighteenth century, and was not, as many have asserted, ${ }^{17}$ the product of the Enlightenment. There is no proof whatever, especially in England, that the proliferation of Christian anticlerical theories in widely available and relatively lowbrow cheap editions were any less influential in politico-religious terms than those of the tiny number of so-called eighteenth-century deists. Anti-Catholics, Dissenters and other religious dissidents were loudly proclaiming the historically demonstrated priestcraft of Catholicism and Anglicanism, and in the process promoting a virulent anticlericalism. In fact, as we shall see, in the life of John Toland it is possible to see the transference of his Dissenter anti-Anglican historical polemic (at some point after 1696 he adopted deistic views) to a new target, that of the Christian ministry in general. However, this is a very different statement from a claim for causal influence upon the formation of the Enlightenment: the anticlerical ideological tool of English dissent was merely that, a tool. In themselves tools cannot exert influence; they must be wielded in definite circumstances.

Emphatically, then, it cannot be said that the dissenting polemical tradition led to the development of the Enlightenment priestcraft theory. But neither should the dismissal of such putative causal links be the occasion to dismiss the general politico-religious background we have identified, for, in conjunction with other events, existing traditions or trends in thought can serve to hamper or aid the development of new trends. England, above all, saw a proliferation of various varieties of vicious anticlerical diatribes, 


\section{The Enlightenment and religion}

which, as we will see, could seem remarkably like the anticlericalism of philosophes.

\section{John Toland, Pierre Bayle and the problem of influence}

If it cannot be asserted that the sceptical/radical tradition or the Christian priestcraft theory produced Enlightenment antichristianism, where should we search for the spurs to such developments? After all, we know that scientific developments of the period certainly did not automatically militate against the Church or religion, ${ }^{18}$ and science and religion in the lives of leading scientists such as Joseph Priestley often went hand in hand throughout the century. Another element of the matrix usually adduced to explain the rise of anticlerical - even irreligious - thinking and the desire for religious pluralism has been that of geographic discovery. This influence, as it has been usually explained, was the realization that morally just societies could exist outside Christianity, that is to say without the Christian clergy which had claimed its role as indispensable in the formation and maintenance of such societies. The problem with this sort of approach is that the identification of influence is never simple, and the theory can easily (and I think more credibly) be turned on its head. It was rather perhaps that our perception of the new Pacific island discoveries was positively coloured by contemporary negative views on the history and role of the clergy, civilization 'weariness' (famously in the work of Rousseau), and even a desire for toleration itself. Thus, Pacific island culture was elevated to a higher level of esteem than was the case with the discovery of 'exotic' cultures long before the Enlightenment. From this perspective, the island societies were confirmation of what was already felt rather than providing any original spur to the critique of the old regime. Broadly speaking, then, the crux of the matter is to determine the relationship between contemporary events and contemporary thought.

We know that Christian anticlericalism and cynicism grew in the early modern period or at least became more visible, encompassed in thousands of publications. We also know that some of those writings were, if generalized, as devastatingly anticlerical as those contained within elite traditions of sceptical thought. This is to say that, in deciding to move away from dissenting thought to a more freethinking position, Toland and a few other radicals had no 


\section{Historians, religion and the historical record}

immediate need to search scarce atheistic writings for anticlerical theory. In a moment of need, they reached for the handiest suitable tool which seemed sufficient for the immediate task: in their case, common-or-garden anticlerical notions. This, of course, is only a contextual example of the fact that once an idea is committed to paper, the author loses control of it, for such dissident Christian critiques were originally developed as necessary tools for the advancement of Christianity, not its abolition. The fact that English radicals commonly embellished and justified their core anticlerical notions by quoting renowned authors we should understand as mere sensible academic practice rather than evidence of influence.

Traditionally, John Toland's Christianity not Mysterious has been understood as a deist work. Yet it can more convincingly be demonstrated that his aim was to show how true Christianity could only be found within the confines of the apostolic - presbyterian model of the Church. For Toland, shortly after the biological demise of the Apostles and their simple non-hierarchical Church, the clergy had mystified religion in order to gain a monopoly over it and the minds of the people. What is truly startling is not the content of Toland's book, but rather the refusal of modern historians to acknowledge the evidence that, at this time, Toland was known as a Unitarian (Socinian), basing his theological outlook on Unitarian views and supported in his views by, amongst others, a leading Quaker. ${ }^{19}$ That he later became what some have termed more deistic (accepting for the moment all the vagaries of that term) in his views is not under contention here. The point is that Christianity not Mysterious was a head-on reforming attack on Anglicanism. That it has been considered a deist work is not surprising, for without study of the dissenting polemical tradition, at first sight dissenting works of this period seem to be written by outright enemies of religion. Toland, as other Dissenters, brought reason enthusiastically to his aid, and we should be very surprised if he did not do so. But, as we shall see, there is still nothing at all contained in Christianity not Mysterious which is not consistent with dissenting politico-religious polemic of the period. This remains the case even with the fact that, as part of normal dissenting prudence, it fails to attack Anglicanism by name, which has been an integral part of the rationale behind claims that it attacked the Christian ministry in general.

For his intended audience - Dissenters and other religious dissidents - there was simply no need to exempt the presbyterian or 


\section{The Enlightenment and religion}

apostolic-style Church from his charge of irredeemable priestcraft, because this was one of the polemical givens of the period. But texts, of course, never have only one audience. Other audiences for Christianity not Mysterious included staunch and ever-vigilant Anglican clergy, who interpreted the text according to their own outlook. Many or most Anglicans knew that Toland never intended to damn dissenting clergy and presbyterianism with his accusation, but for many Anglicans this was of little import. For them, to damn all established or hierarchical Churches since not long after the days of Christ was, in fact, the same thing as condemning the Christian ministry per se. Thus Toland was deemed antichristian and a danger to society. In this manner the manufacture of the myth of the deist movement had begun. The fate of Toland was not, however, unique. Others suffered similar 'misreadings', most famously the Huguenot Pierre Bayle.

Bayle's Dictionnaire historique et critique (1st edn 1695-97) was written and published in the same period of religious crises and persecution. Bayle not only had to flee religious persecution himself, but lost his older brother Jacob, a Huguenot pastor, who died in a dungeon at the hands of those seeking to bring about his 'conversion'. His Dictionnaire quickly acquired recognition for its learned and often daring content. As Toland's Christianity not Mysterious, the Dictionnaire became the touchstone for deists, sceptics and other religious radicals, yet, during the writing of the Dictionnaire, Bayle continued as a genuinely devoted member of the Reformed Church. ${ }^{20}$ As a Protestant who had suffered personal tragedy on account of religious intolerance, it is hardly surprising that he advocated toleration. Like Christianity not Mysterious, the Dictionnaire had, potentially, several audiences. In practice, however, the potential was of a very different order from that in England, in which Dissenters were bitter and disappointed by the limited gains of the Toleration Act (1689), but remained undefeated and full of energy. The Revocation of the Edict of Nantes, the accompanying brutal Dragonnades and the years of persecution which had preceded it, could only be experienced as a decisive defeat for French Protestants. For those historians who wish to chart the career of reason as a symptom of the times rather than a cause, the comparison of Toland and Bayle in 1695-97 is instructive.

Where Toland vaunted reason as the arbiter of right religion and the proof of the iniquity of established Christian ministries, 


\section{Historians, religion and the historical record}

from Bayle's perspective the career of reason looked very different indeed. For Huguenot refugees who had lost family, possessions, livelihoods and property, the seventeenth-century attempt to use reason as a tool for bringing about right religion or at least Christian reconciliation had proven to be a collective catastrophe. For Bayle, at that time, whether it represented majority Huguenot thought or not, it was important to re-evaluate reason. Thus, in his article on reason in the Dictionnaire Bayle explains that reason is an extremely powerful critical tool, but as a defence of faith it is fatally flawed, for reason can always find a method to doubt belief, is capable of inventing difficulties, but incapable of finding solutions. Consequently, he explains that the only refuge for sincere Christians is faith, and faith alone. By faith, however, 'Bayle meant belief in the basic Calvinist doctrines, based on the authority of revelation, and the mysteries common to Catholics and Protestants'. ${ }^{21}$ For Bayle, the doctrines of the orthodox faith were above reason: they could not be understood by reason and therefore could be neither proved nor disproved by reason. This was, of course, hardly a novel sentiment for a Calvinist, but to sceptics, deists and many Catholics he could appear to be a sly sceptic vaunting the power of reason and the defencelessness of Christianity under its assault. Thus, in France, Bayle was unfortunate enough to find strange bedfellows in sceptics, radicals and other 'infidels'.

It is well known that most or all of the philosophes applauded Bayle as an enemy of the Church and claimed him as one of their own. But the ironic thing is that, as Sandberg has pointed out, when Voltaire and the Encyclopedists repeated Bayle's arguments and comments, they were, in turn, repeating material which Bayle himself had taken from the orthodox Calvinist rationalism of his predecessors and contemporaries and simply repeated and embroidered.22 By means of the philosophes and many, many others, Bayle's Dictionnaire found its way into more private libraries than any other single work in the century. As Rex has noted, 'It was one of the most significant influences upon the Encyclopédie, although the fact could seldom be acknowledged'. ${ }^{23}$

It is inconceivable that most of the philosophes, who publicly counted him as one of their own, did not know Bayle was a devoted Christian. Writing in the United Provinces, Bayle had no need of dissimulation for the censor, so his readers knew very well that it could not be claimed he was hiding his radicalism behind a veneer 


\section{The Enlightenment and religion}

of faith. As Sandberg has written, 'those critics who have placed Bayle outside the religious context [i.e. sceptical context] have had to assume that he was forced by the power of the state or the Church to adopt a veneer of orthodoxy in order to get his books published or in order to avoid a fine or imprisonment ... but Bayle wrote and published all of his works in the Republic of Holland and not in France.' The Dutch authorities accepted the principle of religious toleration, and there existed a freedom of the press that was, for all practical purposes, complete. 'It seems evident, then, that if Bayle had really desired to attack the orthodox faith, he could easily have done so directly.' ${ }^{24}$ That Bayle was forthright, even radical in his Calvinist views is in no doubt (his arguments for toleration included Muslims). The condemnation of some elements of his thought by some leading French Protestants further served to make him appear an enemy of the Church, rather than its victim. Modern historians should perhaps marvel at how he managed to keep his faith in such harrowing times, but also note how the historical record can be so potentially misleading. From the English perspective the career of reason might seem to have been the natural direction for progressive Christianity. Clearly Bayle did not agree.

The nature of a writer's opinion at the time of writing is not, then, necessarily the same as the reception of his/her printed opinion. As Labrousse has succinctly put it, the "history of ideas shows that, once removed from its original socio-historical context, and read as the vehicle of a universal message, a work exerts its greatest influence not through the mechanical repetition of the exact reflection of its ideas, but through the ambiguities, misconceptions and anachronisms which find their way into its interpretation. The posthumous influence of Bayle's ideas provides a particularly striking example of the workings of this law. ${ }^{25}$

Of course, it might be replied that Bayle was just an individual. We know, however, that fideism was a significant and credible theological position of the period, and one subscribed to by some considerable numbers. More importantly, given the tolerant views of Bayle and others like him, fideism can hardly be written off as necessarily religiously 'backward', as has too often been the case within Enlightenment studies. As we shall see, the Jansenist movement of mid-eighteenth-century France has also traditionally been defined as religiously backward. ${ }^{26}$ Like Bayle, many committed Jansensists too had little regard for the role of reason in religion, but 


\section{Historians, religion and the historical record}

in those years they developed a specifically Christian foundation for the toleration of Protestants. We should also remind ourselves that most of those progressive radicals, Dissenters and Latitudinarians in late-seventeenth- and early-eighteenth-century England never advocated the unrestricted toleration of Catholics, a fact which, in the modernity stakes, certainly does not put them ahead of midcentury French Jansenists.

In summary, we can say that intellectual developments - in this case Bayle's response to religious persecution - might not seem, if read on a purely textual level, to be a new intellectual development at all, but rather a resurgence of the supposed sceptical tradition stretching back to Renaissance Italy. Instead, we can see that contemporary thought began to 'catch up' with past sceptical thinkers. That is to say, from a range of fairly common-or-garden possible politico-religious responses to the pressure of events and developments, one happened to be chosen that ostensibly resembled a known option within past intellectual frameworks. We might term this a context-interactive or organic process of intellectual change, which is of course very different from the traditional notion of influence proceeding in some disembodied intellectual form from one text to another. Once Bayle was deemed to have opened the breach for Enlightenment scepticism, leading to what many have considered to be a centrally important feature of the dawn of modernity, the 'career' of scepticism was identified. Turning to England, if, on the other hand (and it seems difficult to refute), Toland and the very few other English Dissenters and religious dissidents who became deists began from the traditional radical Protestant critique of established Churches, we could in one sense claim they were influenced by that Christian tradition. But they were, of course, not guided by that influence to attack Christianity, but rather by events. We can speak of a tradition here only in the sense that it was a polemical tradition of potential use for various politico-religious ends. As a polemical tradition it did not possess social force in itself, but was rather an expression of social forces.

\section{Enlightenment from within or without Christianity?}

If elements of traditional Enlightenment studies are open to question, we should perhaps reconsider the very basis for Enlightenment studies: the historical record and the characterizations we extract 


\section{The Enlightenment and religion}

from it. Patrick Collinson has noted that political history has suffered from a retrospective approach, with the construction of developmental stages which may only be the invention of historians. ${ }^{27}$ There are a number of reasons why there may be disagreement on how to characterize and divide up the historical chain into definable periods. Amongst them we can include career interests and specialisms of historians, cultural outlook and ideological factors which may prompt one characterization of a period rather than another. But do these academic disagreements matter? How important is it to address the question of whether, as Peter Gay argued in the 1960s, the Enlightenment came from outside Christianity or was a development from within; or, to cite another example, whether the Enlightenment is to be understood as a clash between reason and religion? If the only issue was the clash between opposing characterizations of the intellectual life of eighteenth-century Europe, with the historical data to provide the ultimate arbiter, then a process of academic conflict and final resolution might be expected. Unfortunately the issue of cutting the chain of history into recognizable chunks is not so one-dimensional. Once a historian has characterized a period, subsequent research agendas (the formation of questions/approaches to historical data) will be generated from inside that general overview. Now, as is accepted by almost all historians, the questions one asks will determine the type of evidence one elicits from the historical record. This is partly because there is too much data for it all to be examined, and, in any case, the same data may be quite legitimately examined from a variety of viewpoints.

One example of particular importance here is the traditional dominance of the characterization of France as a confessional absolutist state. Acceptance of the reality of absolute central rule rather than viewing it as royal rhetoric - has predisposed historians to preclude or downplay the existence of powerful, broad-based debates on the nature of society's political and religious fundamentals. As a consequence, historians have also viewed the struggles of French parlements and church factions as relatively less important in the formation of enlightened thought than might otherwise be the case, for, if debate on the Church was not significant, how could it influence the formation of enlightened thought? In terms of understanding intellectual change and its catalysts, therefore, the question of characterization of historical periods is a very important one. To cite another instance, part of the canon of Enlighten- 


\section{Historians, religion and the historical record}

ment studies from the 1930s to the 1960s was decisively overturned in the late 1960s by Gay's argument that the Enlightenment was a development external to Christianity, a recovery of nerve of freethinkers. Carl Becker's influential The Heavenly City of the Eighteenth-Century Philosophers (1932) took the view that the philosophes were significantly influenced by Christianity even more than they were consciously aware or prepared to admit. Thus the Enlightenment was at least partly a development from existing Christian thought rather than an imposition from without. From the 1960s, however, the general understanding has been that the Enlightenment was influenced by classical and in part Renaissance thinkers, so tending to eclipse Christian influence. This canon, however, is based on mere assumption, above all on the basis of the authorities cited in the writings of the enlightened.

As we have noted, however, citing authorities is more an indication of standard academic or polemical practice and the need to justify arguments, than any necessary gauge of the influences acting upon any given author. Thus the idea that the promotion of a 'civic religion' by some Enlightenment thinkers was the outcome of reading classical philosophico-political texts is a logical but rather simplistic conception of influence. We know that there were longstanding grievances against state and Church which were more likely to provoke writers to express the desire for a different kind of Church in a different kind of society. Most of the radical writers, along with the clergy, government and monarch, also accepted that the Church was necessary to promote an 'acceptable' social peace: without the public assertion of post mortem rewards and punishments, what value would oaths have had? Public and private oaths were still considered to be one of the bedrocks of social order and justice. With all these considerations in mind - and for the moment saving comment upon openly 'atheistic' texts - we must ask ourselves of what use has the outside-inside Christianity distinction been in relation to the origins and development of the Enlightenment? It has, in fact, been a very damaging approach, because at the behest of the modernity thesis it has served to direct research energies disproportionately towards radical texts and 'traditions'. It has also served to conceal somewhat the complexity of social development. As is increasingly recognized, there is no single radical movement or school of thought which can explain the genesis or development of the Enlightenment or at least the enlightened reli- 


\section{The Enlightenment and religion}

gious outlook. In human activity, whether collective or individual, there is often a world of difference between intentionality and final outcome - that is to say, some who wished to promote Christian piety (such as Bayle) unwittingly helped to undermine the traditional religious forms. As Kors has opined, one must consider how 'a complex culture generated its own antithesis, the possibility of which it always had carried within'. ${ }^{28}$

On subjects which were politically, morally, religiously (or in other ways) 'sensitive', many writers would have naturally wanted to avoid mentioning the influence of living individuals, or indeed for a variety of other reasons may have deemed such admission inappropriate for publication. If influence from a past writer was considered not to be acceptable in public eyes, then identification of the source was also naturally to be avoided. Equally as common was the tendency for writers to think it unnecessary to inform us of influences acting upon them because the context or tradition in question was already widely understood, yet something hardly so clear to posterity. The problem of identifying the influence of Christian thought in enlightened works is also compounded by the frequent 'failure' of the authors to acknowledge Christian influences for other reasons. As Kors has noted, such a lack of attribution was common:

Because Enlightenment authors themselves sought to contradistinguish their epoch categorically from the 'orthodox' past, acknowledging as a source of their ideas only, for the most part, what was new in the seventeenth century, scholars often have begun with a similar assumption about influence. What was not part of the 'new philosophy' of the seventeenth century was somehow (however bizarre the assumption appears when stated baldly) without 'positive' influence. ${ }^{29}$

We have said that one of the canons in the study of the enlightened religious outlook has been a teleological approach. To highlight one thinker amongst many, we can note the work of Wade, who traces the intellectual tradition of the philosophes, the 'freethinking tradition', back to 1384 and the Paduan school. ${ }^{30}$ Writers such as Wade have posited schools or movements of thought on the basis of an ostensible similarity of ideas between writers and have presented that 'tradition' as a dynamic within history: as primary causality in the rise of the modern world and modern mind. This type of reification has been very comforting for historians, for it 


\section{Historians, religion and the historical record}

resulted in the finding that their preferred view of the Enlightenment had 'real, objective' intellectual roots. Lest this discussion be misunderstood merely as an attack on those who claim the Enlightenment was a phenomenon of extra-Christian origin, we should note that a similar difficulty is also present in the analyses of theorists such as Kors. The problem has been, he argues, that the sources of the Enlightenment have been 'sought in those thinkers of prior generations who most resembled philosophes, Aufklärers and the "modern" minds of the mid- to late eighteenth century'. ${ }^{31}$ As we have seen, instead he posits that earlier Christian works, 'written from unimpeachable motives of guaranteeing the faith, in fact "cleared the way" for the conceivability of atheistic philosophy'. ${ }^{32}$ If 'cleared the way' means influence, however, then this must be demonstrated or argued for rather than assumed.

Nevertheless, the position of Kors et al. was a welcome move farther away from some of the quasi-conspiracy notions of Enlightenment origins. It was also a step towards a socially broader, more context-based view of origins and, importantly, recognized the potentially important consequences of the difference between intentionality and result in Christian polemic. The problem remains, however, that the question of proof of influence is insufficiently addressed. Some historians are still insufficiently critical of onedimensional accounts of intellectual change, in which intellectual 'traditions' and schemes of thought in themselves possess the power to bring about large-scale intellectual, religious and social change. If we too, for the moment, accept the notion that texts in themselves can possess identifiable social force, we have to ask how we can account for unintended consequences all too apparent, for example, in the reception of Bayle's writings. To say 'unintended' is to argue that, unknown to the author, his work contained more than one message, and that once the arguments were penned he lost control of their direction and other latent messages therein made themselves felt upon the minds of some readers. Put in this way, the argument seems to be postmodern in orientation: that texts themselves are history, but the interpretation of them is a matter for the individual reader and widely divergent readings are all potentially more or less valid. But I cannot accept that texts are, in themselves, history, for there is always something beyond texts which the very fact of them being written, purchased/acquired and read in definite circumstances attests to. 


\section{The Enlightenment and religion}

Texts, of course, only represent what the writer saw fit to tell us, which is a very different thing from knowing the writer's thoughts. In themselves, then, texts will not usually enable us to reconstruct reliably the wider social context of their conception and gestation. Historians can also hardly escape that fact that highbrow texts are rarely fully representative of the intellectual outlook of wider society. Selecting the most 'advanced', most 'modern' texts has of course been a preoccupation in Enlightenment studies. In this way, these more 'bold' texts can seem to be continuations of past radical 'traditions', so seemingly demonstrating the inherent intellectual/social force of that 'tradition'. Poor Bayle, we may add, wrote so incisively that he had to be made to fit into such a tradition. As we have seen, it is very difficult to argue that Enlightenment thinkers came to their conclusions entirely without the influence of the Christian society in which they lived. Yet to argue that Christianity exerted decisive or fundamental influence upon characteristic elements of Enlightenment thought by means of certain relatively elite theological texts is just as problematic. Part of any solution to such a potential impasse lies in the direction taken by Munck in his The Enlightenment (2000), in which he demonstrates that our understanding of the Enlightenment can be enriched from the vantage point of more ordinary people. In particular, Munck demonstrates how mistaken is the common claim that the Enlightenment, as an intellectual and cultural phenomenon, affected only a very tiny minority, instead illustrating how major elements of its aspirations were shared by the middling sort. ${ }^{33}$

\section{The elite and the written record}

Most of the research into Enlightenment thought is based primarily on printed records. The eighteenth-century boom in publishing has meant that we have a rich legacy to mull over, yet, in reality, it represents some of the thoughts of only a tiny fraction of the population. We therefore have massive, even overwhelming gaps in the historical record. In arriving at understandings of the intellectual life of the eighteenth century, however, historians have paid little explicit attention to this problem. The 'rise of irreligion' thesis - the foundation of traditional Enlightenment studies - is thus based on a tiny sample of writers and an assumption about the thought of many more individuals not represented in the historical record. 


\section{Historians, religion and the historical record}

Consequently, this chapter proceeds from the premise that historians have for long been analysing and reporting on the illusion, the ostensible appearance, of a growth of non-Christian or heretical thinking. To put it another way, historians have allowed themselves to become prisoners of the facts of print culture: assuming relatively greater numbers of heterodox and antichristian (considered 'protomodern') tracts in print to be a reliable barometer of intellectual change. Yet there is no necessary direct connection between texts in print and thoughts in heads; and various factors can account for changes in print culture.

The fact remains that the number of overtly Christian publications (sermons, tracts, theological treatises, histories, Bibles, etc.) expanded vastly in the eighteenth century and continued to dwarf those of the enlightened type. Is the great statistical difference between the two publication categories of any real significance? What might it tell us about the intellectual tenor of the period? If we were to use the same barometer of intellectual life as those historians who have viewed the relative rise in publications of a heterodox or antichristian type as an indicator of growth of irreligion or heterodoxy, we should conclude that, overall, society remained very heavily, indeed overwhelmingly committed to Christianity and the supposed antichristian threat amounted to little more than the proverbial wasp around the lion's head. Bare print statistics, of course, tell us potentially very little about the centrally important concept of the texts' significance and influence, which depended on the subject at hand, the cost of publication, the condition of public opinion and, crucially, the audience to which it was addressed. Too often the existence of persistently large numbers of Christian publications has been held to be quite irrelevant to research into the Enlightenment. The result has been that run-of-the-mill religious tracts although perhaps highly critical of the established Church - have for the most part been consigned to the dustbin of historical records because they do not fit the character of 'progressive' enlightened texts.

Of course there are justifiable reasons why the intellectual history of the eighteenth century or of any other period should often be a specialized pursuit, very selective in its delvings into the historical record. Sometimes this is because the historical record is too extensive, and at times because potentially abstruse ideas and debates very often need to be charted with as few complications as possible. 


\section{The Enlightenment and religion}

But this should not be justification for concentrating almost exclusively on elite writings and implicitly stating that, in relationship to investigation of the Enlightenment, the rest of the historical record or indeed the lack of it - is unworthy of examination or consideration. As we have seen, it has by no means yet been established that the formation and transmission of culture is exclusively a one-way top-down process. This has, nevertheless, been a dominant assumption within Enlightenment studies, perhaps even partly a natural outcome of the nature of the subject matter itself. Thus studies of history from below, often seen as challenging the top-down eliteorientated view of history, have been welcomed by many in the broader community of historians who have long felt that intellectual change cannot be properly understood if only elite writings are studied. Yet, in Enlightenment studies, research into the interaction between elite and 'lowbrow' thought still remains marginal, even if studies of elite culture have moved on from the narrow orientation of Peter Gay and his 'family' of philosophes to include a greater spread of thinkers. Thus, beyond set-piece studies of events such as the French Revolution and other revolts where the de facto involvement of the masses in political life cannot be denied, the dominance of the top-down model within Enlightenment studies has rarely been questioned.

Although in itself welcome, the problem with the work of Kors, for instance, is that while striving to show how theological debate had unwittingly fed the Enlightenment, he still retained the traditional purview of a top-down process of influence. In searching to illustrate how learned Christian culture generated components of atheistic thought, he focused insufficiently on the vast bulk of less theological or academic publications or the wider, even popular social, religious and political context. Focusing on a few relatively highbrow publications can be misleading in various ways. It has been commonly asserted, for instance, that one of the great tools of the Enlightenment was the practice of comparative religion. Yet, as we have already noted, comparative religion - indeed an elementary sociology of religion - was developed, propagated and imbibed by the vast bulk of Christians many decades before the Enlightenment, and thus forms one of the several broad intellectual and popular currents which eventually came together to form the Enlightenment. It is not true, however, that elite writings do not tell us anything about influence from below. We know, for instance, that the 


\title{
Historians, religion and the historical record
}

fear of return to the conditions of the English Civil War period or the absolutist strivings of the Stuarts was a vital element of elite and popular consciousness in late-seventeenth- and eighteenth-century England, and consequently cannot be underestimated as a potential factor in the mental matrix which forms the foundation for intellectual development in general. How important those perceptions of the past could be in developing attitudes is illustrated by attempts to claim neutrality for the emerging discipline of science in that period. As Simon Schaffer has noted, the mechanical philosophy was used to create a view of the world beyond the concerns of politics and religion. This attempt to claim neutrality for natural knowledge was of course of great interest to many in post Civil War England, who wished to put a crucial part of intellectual thought potentially beyond the kind of catastrophic divisions of the 1640s and 1650s. But, in practice, an important component of the attempt at neutrality was political. As Schaffer has noted,

\begin{abstract}
Now, the exclusions which surrounded and defined natural philosophy in seventeenth-century England involved various elements: the construction of a purely mechanical model of nature, the denial of the capacity of natural philosophy to deal with souls in nature; the monopoly of natural philosophers over true natural knowledge; and a means by which natural philosophy could act against radical and against 'grovelling Humanity'. Nature itself was to be described as a machine ('a pregnant Automaton' as Boyle described it)..$^{34}$
\end{abstract}

We also know, strange as it may now sound, that Thomas Sprat, the Royal Society's first historian, commended natural philosophy as a cure for sectarian subversion, 'because it debated issues which touched no-one's interest, because it created a technology for the resolution of disputes which might arise, and because it discredited the false pretensions of individual judgement'. ${ }^{35}$

Any claim to neutrality, then, might be damaged if there arose deep divisions and disputes between natural philosophers. For some natural philosophers who feared damaging disputes, Church history told them 'a great deal about how belief could be propagated and how it could be enforced'. Some made an analogy between the elite concerned with natural science and the elite (priesthood) of the Church. In the context of this analogy, in order to help guard against disputes, Jeremy Taylor 'made the suggestion: "raise not thy mind to inquire into the mysteries of state or the secrets of govern- 


\section{The Enlightenment and religion}

ment or difficulties theological, if thy employment really be, or thy understanding be judged to be, of a lower rank", ${ }^{36}$ That fear of division and strife, in part prompted by the memory of catastrophic political and religious division in the Civil War period, was of course also fear of the intellectual involvement of the lower orders and the fruit such involvement might bear. In principle, therefore, if we wish to understand the intellectual outlook of eighteenth-century participants, including the philosophes, we can hardly ignore their attitudes to their present as informed by the past. From this point of view, the Enlightenment, or any other broad intellectual phenomenon, is a developmental process which, to be studied effectively, demands that we examine the interaction of various levels and elements of society.

It is probable that many historians themselves are rarely conscious of the decisively important theoretical assumption behind the dominance of the top-down model of intellectual change. The core of that implicit assumption is that for most of the time the masses were intellectually inert or meekly submissive to the ideology of Church, lord and state, passively waiting for intellectual change from above. So, in terms of the history of the process of secularization, the lower orders are often understood to have been for most of the time little more than mirrors in which ruling-class ideology was reflected. Thus the poor unthinkingly went to Church, believed in the tenets of religion as represented to them by the Church prelacy, feared God, respected the monarch and their betters, and trusted in the government of the country, its laws and the administration of them. Again, the paradox is that, although few historians would be prepared to endorse this characterization without some qualification, it is rare to find a modern historian prepared to accept the obvious corollary: if the lower orders were not mere mirrors of elite culture, it is necessary to question the assumption that intellectual influence is a phenomenon only to be exerted top-down. And, most importantly, if the masses have not been mere mirrors, it is unthinkable that those at the top of society, concerned for a social order dominated by a wealthy elite, were not at times cognizant of that fact.

This proposition is exemplified by the character of the critique of Anglicanism developed by those within the broad dissenting camp and some bold Latitudinarians in late-seventeenth-century England. As Sullivan has illustrated, Toland's Christianity not 


\section{Historians, religion and the historical record}

Mysterious was 'an artifact of this culture, and it cannot be understood if it is approached as a freak' ${ }^{37}$ Prelates, lords and monarch understood how potentially influential the anti-Anglican and antiabsolutist dissenting critique could be, and so did their best to stem the tide by means of severe legal restrictions on Dissenter religious activity, pre-publication censorship, blasphemy laws and bars on holding state posts. Similarly, in France Louis XV was well aware of the potential intellectual power of the non-hierarchical polity of the Huguenots to challenge his absolutist goals. Consequently he revoked the Edict of Nantes in 1685 and subjected the Huguenots to severe physical repression, resulting in one of the greatest religious diasporas of the period.

Another of the characteristic elements of Enlightenment culture has been seen as a secular, modern approach to history. Roy Porter, for instance, has commented that 'for Christian history the proper study of mankind was Providence', while the secular history of the philosophes took as its proper subject the actions of humanity. Similarly, Peter Gay has stated that the developmental dynamic of history as understood by Christians lay 'in the shadow of the supernatural'. ${ }^{38}$ These kinds of formulations, not uncommon, and to an extent useful in order to demonstrate the difference between traditional Christian and Enlightenment historiographical conceptions, are yet potentially most misleading. The uncritical acceptance of such stark divisions has led historians to underestimate the importance and extent of the impact of Christian historical understanding upon the formation of social, political and economic attitudes. Such writers have argued, essentially, that the historiography of the philosophes marked a revolution in the potential of historical writing to influence historical and contemporary conceptions of religion and, by obvious implication, of European civilization. Yet the dissenting critiques of Anglicanism and Catholicism in England were often - and evident to all - profound attacks upon the status quo and rooted in highly pejorative historical analyses, albeit in Christian terms. This was only to be expected, for established religion had a political and economic aspect (public appointments in England, France and Italy, for instance, were barred to the non-orthodox). Christian historico-theological polemic, therefore, was hardly solely concerned with the supernatural and thus without potential influence on secular matters. 


\section{The Enlightenment and religion}

\section{Scaremongering, public opinion and the construction of the deism scare}

As we shall see in the next chapter, it was precisely the interconnections between Church, state, government and the public sphere which enabled - especially in England - the manufacture of one of the great conservative ideological propaganda weapons of the eighteenth century: the threat of organized deists and atheists to Christian civilization. Deism was, above all, a bogeyman created in political debate and print culture. In late-seventeenth-century England the bogeyman of atheism was frequently identified by Anglicans, some of whom wished to make a name for themselves by publicly appearing as staunch defenders of the faith and thus bringing themselves to the notice of their superiors. The problem was that atheists were hardly to be found at all and thus, as a public scare, atheism was less convincing than desired. It was thus necessary to broaden the scope of the threat in order to make it convincing, and there certainly existed those concerned to do so. As Sullivan has expressed it, '[b]y implicitly making deism in its philosophical sense (a watch-like universe and its detached maker) a form of speculative atheism, Samuel Clarke became the first Boyle lecturer to exploit the tactical potentialities of combating this elusive target'. ${ }^{39}$ Another combatant in the fictive war against deism was Humphrey Prideaux, the Dean of Norwich, whose fame rested partly upon his tract against deists entitled Life of Mahomet (1697). ${ }^{40}$ Modern historians, however, having accepted this creation for the public sphere as reality, have used it as prime evidence of emerging 'modernity'. Yet this was not the only ploy - or 'redefinition' - used by Anglican polemicists. Toland, for instance, was repeatedly charged with being a popish agent. This latter charge has not endured, partly because it is unfounded, but also because it is relatively unattractive to historians of the Enlightenment. The fact that charges of popish skulduggery were repeatedly brought into the public domain is significant, however, and indicates something of great importance about the tactics of Anglican polemicists and the use they hoped to make of public opinion - an important topic discussed below. Indeed, it has been suggested that the linking of papists and deists also helped Anglican polemicists avoid the need to answer the tricky arguments of such men as Toland.

Given that this was a period of conflict and uncertainty in reli- 


\section{Historians, religion and the historical record}

gion, it was only natural - as had been the case with the witchcraft persecution - that scapegoats were found, real or imaginary, on whom to lay the blame for perceived problems facing Christianity. More important, the existence of unbelief or 'dangerous' heterodoxy was of some interest to the Church in helping to enlist the active support of the faithful and maintain the defence of the Church. Furthermore - as we shall see in the next chapter - given that clerics and many politicians were personally interested in preserving and strengthening the status quo, it is not surprising that there was a tendency to overstate the actual size of the threat and exaggerate its iniquitous nature. In an effort to promote their own sects, dissenting propagandists were also inclined to exaggerate rather than minimize threats to Christianity as proof that the Anglican Church-state alliance was leading to iniquity. In an age of widening access to print, therefore, it was only natural that elements of this type of strategy would bequeath significant 'evidence' of deism in the historical record greatly disproportional to actual reality. In this period (and indeed into the next century) heresy and unbelief were often sensationalized and significant print-profit was made: religious infidelity was still represented as a lack of moral fortitude and receptivity to vice, conjuring up potentially scandalous scenarios. We might say, then, that the illusion that was eighteenthcentury deism was to some degree a 'media' production.

A few modern writers, however, have realized that a crucial element in understanding the significance of the term deist is the recognition that it was above all a pejorative term, a fairly imprecise insult. It designated, in general, those considered to be in some degree deficient in their faith (and usually outside the recognizable Dissenter parameters). For that very reason, the search for any coherence in the 'movement' has been and will remain fruitless. As Sullivan has put it, 'throughout the eighteenth century, observers placed themselves in the paradoxical position of presuming that deism was a meaningful term, even though they could neither adequately define it nor agree on a list of its advocates' ${ }^{41}$ David Pailin, in 'The Confused and Confusing Story of Natural Religion' (1994), notes that in the seventeenth and eighteenth centuries there were eleven varieties or gradations of what has been termed natural religion, some of which have 'significant sub-divisions'. Consequently, he warns, to ask if a writer was a deist is not a precise or even a fruitful question. ${ }^{42}$ Indeed, there is no reason to suppose a 


\section{The Enlightenment and religion}

term coined as a religious insult should possess precise significance. As he notes elsewhere, the term radical today represents a similar case: its meaning depends on the person who is using it. The term deist 'typically connotes those whom the user considers to be too restricted in what they believe as a result of their understanding of the demands of reason, rather than the adherents of a specifiable set of doctrines'. ${ }^{43}$

Thus there were a number of forms of what has been termed deism and differences between thinkers could be numerous and deep-seated. So, what might seem a profound and useful avenue in the search for Enlightenment origins has, to say the least, dubious value. Perhaps the most contradictory and confusing 'variant' of deism is the so-called 'Christian deism' of such thinkers as Thomas Morgan, ${ }^{44}$ Woolston and Tindal. Deists, according to the traditional canon, refuted revelation in favour of reason. If the term deism is to have any such coherence, how can the revelation of Christ be reconciled with the deist denial of revelation? We must be alert, therefore, to the potential for thinkers to hold what to us might seem to be contradictory positions, but for them were resolvable on a personal basis. Thus, without denying the tabula rasa theory ( $A n$ Essay Concerning Human Understanding, 1689) of John Locke, Tindal insisted that God 'had implanted in our Natures a Sense of Piety, and a Desire of being belov'd, in order to oblige Mankind to treat one another kindly'. This notion may be broadly reconcilable with a deistic outlook, but still on the subject of the implantation of a sense of piety, Tindal went on to say that God continued 'daily to imprint it'. ${ }^{45}$ From the point of view of both deistic views and the censor this further point is unnecessary and strongly indicates his sincerity. Believing in the 'daily imprint' of God's design is hardly writing providence out of daily life, yet deism has traditionally been considered one of the great secularizing forces of the Enlightenment. It is not surprising, then, that the attempt to attribute a characteristic deism to various thinkers has been termed 'a matter of convenience rather than an aid to analysis' ${ }^{46}$ To add to the confusion, historians have tended to identify any thinker who wrote works with the terms 'natural religion' or the 'religion of nature' in their titles as deists, as in the case of Wollaston's Religion of Nature Delineated (1724). Yet, as the Appendix at the end of this book indicates, the topic of natural religion (or the religion of nature) and its acceptance within or alongside Christianity was common within 


\section{Historians, religion and the historical record}

Christian literature of this period, and was certainly not a subject reserved only for the numerous hostile replies to perceived enemies of Christianity.

The Enlightenment period was still in good part one of the confessional state, or significant degrees of it, hence public appearances really did matter to some extent. The potential differences between private and public religious views, therefore, obviously warrant considerable attention. In pre-Revolution France, for instance, it has been noted that some of those who came to Mass came from a sense of religious, social, political and even economic duty, yet were unable to refrain from venting their anticlericalism in various, often disruptive and scandalous manners. ${ }^{47}$ This is a tale by no means exclusive to France, and demonstrates how figures for church attendance must be treated with the same extreme caution. As the case of English dissent amply demonstrates, it was of course possible to be quite pious, yet hold profoundly anticlerical views whilst paying public lip-service to Church and state when circumstances absolutely demanded it. In such instances there was no necessary contradiction between the formal recognition of established religious forms and anticlerical thought and behaviour. From the point of view of recovering the past, the private-public problem applies to the social scale at all levels, for, although individuals on the upper levels were more likely to leave some written evidence of their religious views, much of that extant record was for public consumption.

I am advocating, therefore, that it is necessary to construct a model of Europe's religious past that is more dynamic, one in which anticlericalism and piety may often go hand in hand, and one in which the tension between official and private views is acknowledged. To do so, in effect, is to recognize public opinion as a cultural reservoir of forms of anticlericalism and 'infidelity' and the everpresent possibility of it being tapped. The existence of a variety of anticlerical ideas should be assumed as the norm, ever balanced against and in tandem with degrees of piety and submission to the Church. In this circumstance, the necessity of hypothesizing about influence from past anticlerical traditions as the key to the origins of Enlightenment anticlericalism is, if not removed, then significantly attenuated.

Since the publication of Habermas's The Structural Transformation of the Public Sphere (1989), ${ }^{48}$ it has been generally accepted 


\section{The Enlightenment and religion}

that the birth of public opinion as a political force came about in the eighteenth century. Habermas argued that in late-seventeenthcentury England and late Enlightenment France a secular 'bourgeois' public sphere began to develop that marked the arrival of the undeniably powerful and supposedly modern phenomenon we term public opinion. In the view of Habermas the 'birth' of the public sphere was the outcome of long-term trends, namely the gradual coalescence of nation-states and the beginnings of capitalism. ${ }^{49}$ As we shall see in subsequent chapters, whether or not there may be some sense in focusing on those factors in the development of modernity, the notion that traditional 'non-modern' forms of politico-religious struggle were not central in the widening of the public sphere in Enlightenment Europe cannot easily be sustained. In wishing to chart the origins of secular modernity, then, Habermas tended to ignore or downplay the traditional politicoreligious content of the emerging public sphere and disproportionately to highlight the 'modern' secular elements.

Happily, John McManners (Church and Society in EighteenthCentury France, 1998), building on the 1980s research of Baker, Echeverria and to some degree Chartier, ${ }^{50}$ has sought to recognize politico-religious public opinion as a significant political and social force in Enlightenment France, that is to say constituting a powerful public sphere. Baker and Echeverria argued that the early 1770s when Louis XV made his final play to cow his rebellious parlements by abolishing them (the Maupeou revolution) - was the period when public opinion as a political force was born. Louis's action brought forth a tidal wave of popular and learned literature appealing to the nation against despotism. McManners agrees that this "brought the empire of "public" opinion to general acceptance, not only by its force and reverberation, but by its direct concentration on the central political issue of power and by its eventual triumph'. But he also notes that '[p]robably, however, [the sway of public opinion] ... should be dated a decade earlier, when the storm of public reprobation swept down upon the Society of Jesus'. ${ }^{51}$ That 'storm' was led by Jansenists and its body was composed of vast numbers of Jansenist sympathizers. Yet that 1760s storm was not of a fundamentally different nature from other Jansenist-inspired politico-religious storms that had erupted in France since 1715, and hence the view that the birth of the public sphere in France was a 'secular' late Enlightenment phenomenon is problematic. 


\section{Historians, religion and the historical record}

Habermas naturally highlights print culture as an important facet of the public sphere. That there was a large increase in the numbers of published works of all types in the eighteenth century, especially in the latter half, and a consequent increase in the printbuying public (although such figures tend to underestimate literacy levels), is now an accepted fact. Even those of quite modest means were able to purchase popular or more learned texts of an increasingly wide variety. This was, of course, an important development in terms of the dissemination of new ideas, and as such had an impact on public opinion. Crucially, we must emphasize, however, that in this context the use of the term public opinion has a different, more passive connotation than McManners's more reactive, politically directed concept of an 'empire of public opinion'. When, on account of the public storm which swept down upon the Jesuits, he suggests that the rise of public opinion should be dated to the 1760s, he is also noting that decisive political battles (the Jesuits were identified with despotic Bourbon rule) can be fought in an ostensibly religious form. Thus the formation or creation of public opinion cannot always be distinguished from the various potential forms of its expression: whether actively in the public domain by printed matter, by physical manifestation, by political manoeuvre, by clandestine activity, by passive non-compliance, etc.

When historians describe the great religious propaganda print battles of the sixteenth and seventeenth centuries, they can only be describing attempts to create and/or express public opinion. Those religious propaganda campaigns were rarely without political content or implications, and their duration for decade after decade indicates that they were regarded as an effective means by which to promote the views of their protagonists. As Tyacke has written, 'it will not do to argue, as some have, that doctrine was of little relevance to ordinary people. We are in fact dealing with some of the intellectual underpinnings of popular religious observance.' 52 Some of the circumstances and statistics of early modern attempts to mould public opinion are significant. Between 1517 and 1520, for example, Martin Luther had published at least thirty major pamphlets in a popular style and plain German language totalling, it is estimated, more than 300,000 copies. $^{53}$ Beside these, there were theatre performances demonstrating papal depravity, the propaganda use of the hymn, poetic versions of Luther's doctrine and propagandistic woodcut prints. Apparently, woodcut caricatures of 


\section{The Enlightenment and religion}

the Pope were selling very well in Nuremburg in 1523. In England, the late sixteenth century saw the popular and notorious Puritan Martin Marprelate tracts, which were hostile to the hierarchy of the Anglican Church and written in probably the most brilliant prose satire of the period.

In the seventeenth century, pamphlets and other popular publications began more than ever to contribute to the formation of public opinion, and reached new heights of influence in England in the tumultuous 1640s and 1650s (Civil War, Republic and Protectorate period), and during the Thirty Years War (1618-48). The Thomason collection for the period 1640-62 totals 30,000 separate titles and editions of books, pamphlets, satires and broadsides. In the Thirty Years War there was a wide proliferation of pamphlets and posters sold in large quantities in shops, so much so that all classes of the population were reached by the polemical output. Early modern rulers, like their forebears, did not ignore the value of propaganda, now enhanced with print technology. The Holy Roman Emperor Maximilian gave patronage at his court for imagebuilding initiatives, and Oliver Cromwell did likewise. ${ }^{54}$ From the bottom to the top of early modern society, therefore, it was recognized that public opinion existed and could be cultivated and directed towards certain ends. We know that King Louis XIV of France authorized a propaganda campaign to cultivate support for his government's brutal suppression of the Huguenots. Pamphlets of a popular nature recounting Calvinist 'outrages' were hawked in the streets of towns and villages in order to support the decrees, edicts and declarations against the Huguenots and so justify their cruel reality. Monarchs and rulers clearly thought public opinion was not to be ignored without risk, a point demonstrated in the celebrated 1616 decision of the papacy to condemn the heretical astronomical finding of Copernicus.

There is evidence to suggest that in 1616 Rome had correctly assessed that there was still little broad support for Copernicus's ideas of 1543, and that which existed was not viewed as a significant threat to biblical orthodoxy that the Earth was at the centre of the universe. Rome was forced into the defensive action of 1616 not on account of any broad scientific threat. Rather it was prompted to act in order to combat the growing threat to Roman orthodoxy and biblical doctrine posed by the widespread and far-reaching antiRome polemic of Protestants, that is to say European public opin- 


\section{Historians, religion and the historical record}

ion. The key Protestant charge in this context was that the papacy had tampered with the Bible. As Sella has explained, if the Bible were not to be considered literally true in its account of the universe, 'it might lend credence to Protestant charges that the Catholic Church took liberties with the sacred text. Accordingly, they fell back, defensively, on uncompromising, literalist exegetical standards. ${ }^{55}$ There is reason, therefore, to question the consistency of the traditional story many historians have propagated: that of the selfsacrificing battle of the principled scientist against a backward hierarchy of clerics. At least some of that battle is romantic fiction.

If, however, we wish to identify the role of public opinion in the formation of important elements of Enlightenment context, England in the 1670s and 1680s is an important example. William of Orange of the United Provinces was well informed that English public opinion was increasingly unsympathetic to the "poperyinspired' absolutist tendencies of the Stuarts, and decided he could exploit it in the interests of the United Provinces, then at war with France and England. As we will see, his propaganda campaign in England, linking the Stuarts to popery and despotism, was highly successful, contributing to the growing political pressure upon King Charles. This and other examples demonstrate the importance of the public arena in late-seventeenth-century England, and it is a crucial factor to be included in any attempt to understand the pace and direction of politico-religious change. With public opinion now more convinced than ever that the King was in conspiracy with popish forces, the pervasive anti-popish hysteria of 1673 did not fully abate in the following years. As a consequence, the wildest tales of conspiracy circulated and gained credence. Throughout the 1670s these crises (as we shall see, in important respects similar in their impact to events in mid-century France) continued, with public opinion a centrally important factor. It has been estimated, for example, that in addition to large numbers of petitions the attempt to prevent the Catholic King James II from inheriting the throne (the Exclusion Crisis, 1679-81) generated between five and ten million pamphlets, ${ }^{56}$ as well as the origin of Locke's celebrated Two Treatises of Government (1689). So, far from non-existent, or embryonic, early modern public opinion played a crucial role in some of the most dramatic events in English history. It contributed greatly towards the most astounding events leading up to and including those of 1688, when Catholic James II, with wide support, was told 


\section{The Enlightenment and religion}

he was being replaced by William of Orange. This act saw the final step taken in the irrevocable dominance of Parliament over the God-given monarch and thus the mass de facto withdrawal of allegiance from the long-standing theory of the divine right of kings. ${ }^{57}$ In essence, it can be said, then, that English late-seventeenth-century public opinion accomplished a definite and relatively rapid step in the secularization of society.

To talk, therefore, of the gradual secularization of early modern society, which is the traditional description of the secularization process, can be quite misleading. It was a process that was neither quantitatively nor qualitatively linear. In any case, the term secularization, as commonly used, is also problematic, because it is often intended and understood as denoting how far state institutions, laws and processes are framed and proceed from secular imperatives rather than divine. It hardly needs affirming, surely, that public opinion - or sections of it - may become more secular in its outlook at a different rate from changes in political forms. For observers to measure this change via the various European landmarks of governmental debate, legislation, or scientific advance, is merely to note how two rarefied spheres of thought (government and elite intellectual) have responded to certain broader circumstances and challenges. Their responses, however, may be in harmony, in advance or, as was the case with public support for the recognition of Huguenot marriage in France, just as easily a step behind the process of secularization of social and religious attitudes.

Another traditional means of cultivating public opinion was of course that of the pulpit, and its importance was not underestimated in the eighteenth century. As we shall see in the next chapter, probably the most adroit cultivation of public opinion in Enlightenment England was that achieved by the High Church Henry Sacheverell, who in 1709 wielded the Church-in-danger cry with dramatic effect. From the pulpit of St Paul's, this staunch Anglican managed to conjure up in the public mind a Dissenter threat wildly out of proportion to reality, and in the process decisively rallied the political fortunes of the rigidly Anglican Tory party. ${ }^{58}$ During the great public controversy surrounding the so-called Jew Bill of 1753 , for example, the Tories again used the pulpit, their traditional medium, mobilizing Anglican clergy to preach against the Bill. Both Whig and Tory, however, utilized the press and mobilized through 


\section{Historians, religion and the historical record}

the traditional channels of coffee-house readership and pamphlets. Newspapers and magazines from London to the midlands carried the debate forward. Sixty pamphlets against the Bill were published in one year alone, some using anti-Semitic arguments. The Tories also used a series of public relations activities and ploys - rallies, dinners, banners - and women wore ribbons or crosses carrying effigies of Jews; 'it thus became a stigma not to wear some anti-Bill identification'. ${ }^{59}$ At the more popular end of the propaganda scale, therefore, the distinction between the creation and expression of public opinion can at times seem vague, for the mass expression of public opinion can further reinforce and/or modify its content and scale of impact upon the political and social order. As we will see in the case of mid-century France, at certain moments, what might be termed an organic or collective dynamic of intellectual change can be identified, when the normal processes of politico-religious maturation are accelerated via the concentrated and speeded-up events of public urban discourse and demonstration.

\section{Notes}

1 P. Riley, The General Will Before Rousseau. The Transformation of the Divine into the Civic (Princeton, N.J.: Princeton University Press, 1986), p. x.

2 I. Wade, The Intellectual Origins of the French Enlightenment (Princeton, N.J.: Princeton University Press, 1971), p. 655.

3 C. J. Betts, Early Deism in France. From the So-Called 'Déistes' of Lyon (1564) to Voltaire's 'Lettres philosophiques' (1734) (The Hague, Boston and Lancaster: Martinus Nijhoff, 1984), p. 5.

4 Ibid., p. 235.

5 Ibid., pp. 4-5.

6 A. C. Kors, Atheism in France, 1650-1729. Vol. 1: The Orthodox Sources of Disbelief (Princeton, N.J.: Princeton University Press, 1990), p. 4.

7 A. C. Kors, "A First Being, of Whom We Have No Proof”. The Preamble of Atheism in Early-Modern France', in A. C. Kors and P. J. Korshin (eds), Anticipations of the Enlightenment in England, France and Germany (Philadelphia: Philadelphia University Press, 1987), p. 18.

8 Paul Korshin, Elisabeth Labrousse, Dale Van Kley and Margaret Jacob collaborated on the collection of articles in Anticipations of the Enlightenment.

9 D. Van Kley, 'Pierre Nicole, Jansenism, and the Morality of Enlightened SelfInterest', in Kors and Korshin (eds), Anticipations of the Enlightenment, p. 69.

10 Kors, “"A First Being, of Whom We Have No Proof”, pp. 17-18.

11 G. R. Cragg, Reason and Authority in the Eighteenth Century (Cambridge: Cambridge University Press, 1964), p. 32.

12 D. Pailin, 'Herbert of Cherbury. A Much Neglected and Misunderstood 


\section{The Enlightenment and religion}

Thinker', in P. Creighton and E. Axel (eds), God, Values and Empiricism. Issues in Philosophical Theology (Macon, Ga.: Mercer University Press, 1989), pp. 171-2, 177.

13 For a relatively recent assertion of this tradition see J. Byrne, Glory, Jest and Riddle. Religious Thought in the Enlightenment (London: SCM Press, 1996), pp. 28-9.

14 Ibid., p. 29.

15 A. Milton, Catholic and Reformed. The Roman and Protestant Churches in English Protestant Thought (Cambridge: Cambridge University Press, 1995), pp. 173-4.

16 On comparative anticlerical theories see my Idol Temples and Crafty Priests. The Origins of Enlightenment Anticlericalism (London: Macmillan, 1999).

17 See, for instance, D. Outram, The Enlightenment (Cambridge: Cambridge University Press, 1995), p. 40, on the 'new field of study of comparative religion'; and a similar analysis from J. Champion in 'Europe's Enlightenment and National Historiographies: Rethinking Religion and Revolution (1649-1779)', Europa. European Review of History, 0 (1993), p. 84.

18 See, for instance, T. Hankins, Science and the Enlightenment (Cambridge: Cambridge University Press, 1995), p. 145. On the unprecedented fusion of science and religion in seventeenth-century England see, for instance, A. Funkenstein, Scientific Imagination from the Middle Ages to the Seventeenth Century (Princeton, N.J.: Princeton University Press, 1986).

19 R. Sullivan, John Toland and the Deist Controversy (Cambridge, Mass.: Harvard University Press, 1982), pp. 9, 23, 110-11, 274.

20 See W. Ward, Christianity under the Ancien Régime 1648-1789 (Cambridge: Cambridge University Press, 1999), p. 159, on Bayle's active membership of the reformed church while writing the Dictionnaire.

21 K. Sandberg, At the Crossroads of Faith and Reason. An Essay on Pierre Bayle (Tucson: University of Arizona Press, 1966), p. 2.

22 Ibid., pp. 38-9.

23 W. Rex, Essays on Pierre Bayle and Religious Controversy (The Hague: Martinus Nijhoff, 1965), p. x.

24 Sandberg, At the Crossroads of Faith and Reason, pp. 99, 103.

25 E. Labrousse, Pierre Bayle (Oxford and New York: Oxford University Press, 1983; 1st edn 1963), p. 90. See also E. Labrousse, 'Reading Pierre Bayle in Paris', in Kors and Korshin (eds), Anticipations of the Enlightenment, p. 11.

26 This estimation even prevails today; see for instance Ward's Christianity under the Ancien Régime, pp. 166-7.

27 P. Collinson, The Birthpangs of Protestant England. Religions and Cultural Change in the Sixteenth and Seventeenth Centuries (Basingstoke: Macmillian, 1998), p. 83.

28 Kors, Atheism in France, pp. 4, 379.

29 A. C. Kors, 'Introduction', in Kors and Korshin (eds), Anticipations of the Enlightenment, p. 2.

30 Wade, The Intellectual Origins, p. 655.

31 Kors and Korshin (eds), Anticipations of the Enlightenment, p. 2.

32 Kors, “"A First Being, of Whom We Have No Proof”', pp. 17-18.

33 Ward, Christianity under the Ancien Régime, to cite a recent example, gives the 


\section{Historians, religion and the historical record}

percentage of the European population touched by the Enlightenment as 10 per cent.

34 S. Schaffer, 'The Political Theology of Seventeenth-Century Natural Science', Ideas and Production, 1 (1983), p. 4. On politics and science see also S. Shapin and S. Schaffer, Leviathon and the Air-Pump. Hobbes, Boyle, and the Experimental Life (Princeton, N.J.: Princeton University Press, 1985), especially chs 7-8.

35 Schaffer, 'The Political Theology', p. 5. For a similar analysis see also D. Zaret, Origins of Democratic Culture. Printing, Petitions and the Public Sphere in Early Modern England (Princeton, N.J.: Princeton University Press, 2000), pp. 270-5.

36 Schaffer, 'The Political Theology', pp. 5-7, 11.

37 Sullivan, John Toland and the Deist Controversy, p. 51.

38 Roy Porter, The Enlightenment (Basingstoke: Macmillan, 1990), p. 72; Peter Gay, The Enlightenment: An Interpretation. Vol. 2: The Science of Freedom (London: Wildwood House, 1973; 1st edn 1969), p. 386.

39 Sullivan, John Toland and the Deist Controversy, pp. 236, 239-40.

40 Prideaux's A Life of Mahomet (1697) was preceded by his A Letter to the Deists (1696).

41 Sullivan, John Toland and the Deist Controversy, p. 212.

42 On the difficulties of defining deism, in addition to the works cited in the previous chapter, see also Pailin, 'Herbert of Cherbury'; J. C. D. Clark, English Society 1688-1832. Ideology, Social Structure and Political Practice during the Ancien Régime (Cambridge: Cambridge University Press, 1985), p. 279; and D. Nicholls, God and Government in an Age of Reason (London and New York: Routledge, 1995).

43 D. Pailin, 'British Views on Religion and Religions in the Age of William and Mary', Method and Theory in the Study of Religion, 6: 4 (1994), p. 354. Rivers makes a similar comment in her Reason, Grace and Sentiment. Vol. 2: Shaftesbury to Hume (Cambridge: Cambridge University Press, 2000), p. 5.

44 On the assertion of the Christian deism of, for instance, Thomas Morgan, see Peter Gay, The Enlightenment. An Interpretation. Vol. 1: The Rise of Modern Paganism (London: Norton, 1995; 1st edn 1966), p. 375.

45 M. Tindal, The Rights of the Christian Church (4th edn, London, 1708), p. 114, and Christianity as Old as the Creation (London, 1730), pp. 59-60, quoted in Sullivan, John Toland and the Deist Controversy, p. 229. In his God and Government in an Age of Reason (pp. 144-5), Nicholls too notes that 'some deists appear to have accepted the notion of divine revelation'.

46 Sullivan, John Toland and the Deist Controversy, p. 232.

47 J. McManners, Church and Society in Eighteenth-Century France (2 vols, Oxford: Clarendon Press, 1998), vol. 2, pp. 99-100, 103-4.

48 J. Habermas, The Structural Transformation of the Public Sphere. An Enquiry into a Category of Bourgeois Society, trans. Thomas Burger (Cambridge, Mass.: MIT Press, 1989; original edition in German 1962). Habermas's ideas only gained a wider hearing after the 1978 French translation.

49 For a useful summary and discussion of Habermas's views see T. Dykstal, The Luxury of Skepticism. Politics, Philosophy and Dialogue in the English Public 


\section{The Enlightenment and religion}

Sphere 1660-1740 (Charlottesville: University Press of Virginia, 2001), pp. 1-15.

50 K. Baker (ed.), The French Revolution and the Creation of Modern Political Culture. Vol. 1: Political Culture of the Old Regime (Oxford: Pergamon, 1987);

D. Echeverria, The Maupeou Revolution. A Study in the History of Libertarianism. France 1770-1774 (Baton Rouge: Louisiana State University Press, 1985); R. Chartier, The Cultural Origins of the French Revolution (Durham, N.C.: Duke University Press, 1991).

51 McManners, Church and Society in Eighteenth-Century France, vol. 2, pp. 534,672 .

52 N. Tyacke, Aspects of English Protestantism c.1530-1700 (Manchester and New York: Manchester University Press, 2001), p. 13.

53 O. Thomson, Mass Persuasion in History (Edinburgh: Paul Harris, 1977), p. 76.

54 Ibid., pp. 77-80.

55 For a discussion on the Tridentine revival and the decision of 1616 see D. Sella, Italy in the Seventeenth Century (Harlow: Longman, 1997).

56 M. Knights, Politics and Opinion in Crisis, 1678-81 (Cambridge: Cambridge University Press, 1994), pp. 168, 227-305.

57 Few dared openly to proclaim their loyalty to James II as the legimate king. The only identifiable (although small) body to do so were the so-called Nonjurors.

58 For a clear account of the Sacheverell affair, see G. Holmes, The Trial of Doctor Sacheverell (London: Methuen, 1973).

59 Thomson, Mass Persuasion, p. 83. 